\title{
Herbivorous Insect Response to Group Selection Cutting in a Southeastern Bottomland Hardwood Forest
}

\author{
MICHAEL D. ULYSHEN, ${ }^{1,2}$ JAMES L. HANULA, ${ }^{1}$ SCOTT HORN,${ }^{1}$ JOHN C. KILGO,${ }^{3}$ AND \\ CHRISTOPHER E. MOORMAN ${ }^{4}$
}

Environ. Entomol. 34(2): 395-402 (2005)

\begin{abstract}
Malaise and pitfall traps were used to sample herbivorous insects in canopy gaps created by group-selection cutting in a bottomland hardwood forest in South Carolina. The traps were placed at the centers, edges, and in the forest adjacent to gaps of different sizes $(0.13,0.26$, and $0.50 \mathrm{ha})$ and ages ( 1 and 7 yr old) during four sampling periods in 2001 . Overall, the abundance and species richness of insect herbivores were greater at the centers of young gaps than at the edge of young gaps or in the forest surrounding young gaps. There were no differences in abundance or species richness among old gap locations (i.e., centers, edges, and forest), and we collected significantly more insects in young gaps than old gaps. The insect communities in old gaps were more similar to the forests surrounding them than young gap communities were to their respective forest locations, but the insect communities in the two forests locations (surrounding young and old gaps) had the highest percent similarity of all. Although both abundance and richness increased in the centers of young gaps with increasing gap size, these differences were not significant. We attribute the increased numbers of herbivorous insects to the greater abundance of herbaceous plants available in young gaps.
\end{abstract}

KEY WORDS selection cutting, uneven-aged silviculture, forest openings, forest management

WHILE THE EFFECTS OF insect herbivory on plant communities and rates of succession have been well studied (Breedlove and Ehrlich 1968, Brown 1984, 1985, Hendrix et al. 1988, Brown and Gange 1992, McBrien et al. 1983), relatively little is known about how plant succession affects herbivorous insects (Bach 1990). Given the relative abundance of young herbaceous growth in early stages of succession, one might expect to find increased numbers of herbivorous insects there compared with more mature habitats. Indeed, past work recognizes the importance of increasing taxonomic and structural diversity of plants to the creation and maintenance of a diverse insect community during succession (Murdoch et al. 1972, Lawton 1978, Southwood et al. 1979), and several features of the plants themselves may encourage herbivory in recently created habitats. These include increased nutrient levels (i.e., soluble nitrogen) in plant tissues (Boardman 1977, McNeill and Southwood 1978, Mattson 1980), reduced plant defenses in many pioneer species (Coley 1983, Lawton and McNeill 1979), and increased consumption and growth rates of herbivorous insects that feed on plants receiving direct sunlight (White 1978, Scriber and Slansky 1981). The

${ }^{1}$ USDA Forest Service, Southern Research Station, 320 Green Street, Athens, GA 30602-2044.

${ }^{2}$ Corresponding author, e-mail.mulyshen@hotmail.com.

${ }^{3}$ USDA Forest Service, Southern Research Station, Savannah River Site, PO Box 700, New Ellenton, SC 298093.

${ }^{4}$ North Carolina State University, Department of Forestry, Box 8003, 3028E Biltmore Hall, Raleigh, NC 27695-8003. situation is complicated by a number of factors that seem to discourage herbivory, however. For example, increased light levels may be beneficial in terms of insect growth rates, but they have also been shown to increase the toughness of leaves and, in some cases, the concentration of defensive compounds (Shure and Wilson 1993).

In many forests, canopy gaps created by treefalls, wind damage, and other minor events serve as important centers of plant growth and succession (Runkle 1981, 1982, White et al. 1985, Phillips and Shure 1990, Clinton et al. 1993). The increased availability of light, water, and nutrients in gaps increases plant diversity and net primary productivity and encourages the growth and regeneration of less shade tolerant species (Bormann and Likens 1979, Boring et al. 1981, Brokaw 1982, Phillips and Shure 1990, Wilder et al. 1999). Predicting the response of herbivorous insects to such complicated and dynamic environments is difficult and quickly confounded by factors such as gap size and age. Large gaps, for example, receive more sunlight than small gaps (Shure and Wilson 1993), creating differences in soil moisture and plant growth (Shure and Phillips 1991). The plant communities present in gaps of differing age and stage of succession should be quite different, with unknown implications to the insect community. In this paper, we compare the species richness, abundance, and composition of herbivorous insects in artificial canopy gaps of different size $(0.13,0.26$, and $0.50 \mathrm{ha})$ and age ( 1 and $7 \mathrm{yr}$ old) in a bottomland hardwood forest in the south- 
eastern United States. The gaps were created by group-selection cutting, an uneven-aged forest management practice that removes patches of merchantable trees leaving small ( $<0.55 \mathrm{ha})$ openings similar to those created by insect infestations, severe wind damage, or other localized disturbances (Hunter 1990, Guldin 1996, Meadows and Stanturf 1997).

\section{Materials and Methods}

This study was conducted on the Savannah River Site (SRS), an 80,269-ha nuclear production facility near Aiken, SC. The SRS is owned and operated by the U.S. Department of Energy and is managed as a National Environmental Research Park. The stand used was a 75- to 100-yr-old bottomland hardwood forest $\approx 120$ ha in size. The forest canopy consisted of bald cypress (Taxodium distichum L.), laurel oak (Quercus laurifolia Michaux), willow oak (Q. phellos L.), overcup oak (Q. lyrata Walter), cherrybark oak (Q. falcata variety pagodaefolia Elliott), swamp chestnut oak (Q. michauxii Nuttall), sweetgum (Liquidambar styraciflua L.), red maple (Acer rubrum L.), and loblolly pine (Pinus taeda L.). The midstory consisted predominantly of red mulberry (Morus rubra L.), ironwood (Carpinus caroliniana Walter), and American holly (Ilex opaca Aiton). The understory was dominated by dwarf palmetto [Sabal minor (Jacquin) Persoon] and switchcane [Arundinaria gigantean (Walter) Muhlenberg].

Of the 24 gaps used in this study, 12 were created in December 1994 (old gaps) and 12 in August 2000 (young gaps). For both young and old gaps, there were three different sizes $(0.13,0.26$, and $0.50 \mathrm{ha})$, each replicated four times. At the time of sampling, the vegetation in the old gaps ranged from 1 to $8 \mathrm{~m}$ in height and consisted of pioneer species such as sweetgum, sycamore (Platanus occidentalis L.), green ash (Fraxinus pennsylvanica Marshall), black willow (Salix nigra Marshall), tulip poplar (Liriodendron tulipifera L. ), oaks, switchcane, and dwarf palmetto. Young gaps also contained seedlings and stump sprouts of the tree species above plus an abundance of fireweed (Erechtites hieracifolia L. Rafinesque), blackberries (Rubus spp.), plumegrass [Erianthus giganteus (Walter) $\mathrm{Mu}$ hlenberg], and various grass and sedge (Cyperus spp.) species. Young gaps generally had a much more diverse herbaceous layer and numerous sprouts arising from tree stumps and roots, whereas older gaps and the surrounding forest had comparatively little herbaceous growth. Competition with young trees limited the amount of herbaceous vegetation in old gaps, but they still contained more herbaceous growth per unit area than the nearby forest (L. Bowen, personal communication).

Insects were sampled four times in 2001 (17-23 May, 10-16 July, 7-13 September, and 3-9 November) at three locations (gap center, gap edge, and in the forest $50 \mathrm{~m}$ from gap edge) in and around each gap. Overall, we sampled for $4 \mathrm{wk}$ in each of the 72 locations. Each sample location had a malaise trap (Canopy Trap; Sante Traps, Lexington, KY), suspended from a 3-m- long pole to capture flying insects, and two pitfall traps to capture ground-dwelling insects. The pitfall traps were placed $5 \mathrm{~m}$ apart at each sample location and consisted of a $480-\mathrm{ml}$ plastic cup buried to ground level. A small funnel ( $8.4 \mathrm{~cm}$ diameter) was inserted into the mouth of the cup to direct captured insects into a smaller 120-ml specimen cup below. The cup was positioned at the intersection of four 0.5 -m-long drift fences. The malaise and pitfall trap samples at each location were combined before analysis. The collecting jars for both pitfall and malaise traps were filled with a NaCl-2\% formaldehyde solution to preserve specimens, and a drop of detergent was added to reduce surface tension (New and Hanula 1998). Once collected, the insects were brought back to the laboratory and immediately stored in $70 \%$ alcohol. Specimens were sorted and later identified to morphospecies. We included the following herbivores (by order and family) in our analyses: Coleoptera: Chrysomelidae; Lepidoptera: larvae of all families; Thysanoptera: all families; Orthoptera: Acrididae and Tettigoniidae; Homoptera: Achilidae, Aphididae, Cercopidae, Cicadellidae, Cixiidae, Delphacidae, Derbidae, Flatidae, Issidae, Membracidae, and Psyllidae; Hemiptera: Lygaeidae, Miridae, and Pentatomidae. We examined adult Lepidoptera in separate analyses because they may indicate the presence of larvae but are not themselves actively herbivorous.

A three-way analysis of variance (ANOVA) with abundance and richness as response variables and gap age, trap location, and gap size as the main effects showed a significant interaction between gap age and location, so we analyzed the data for each age separately. Data were analyzed using the general linear model procedure of SAS (SAS Institute 1985), and the Ryan-Einot-Gabriel-Welsch multiple range test $(\alpha<$ $0.05)$ was used to determine differences in relative abundances of insects between trap locations or gap sizes for each gap age. We also calculated the percent similarity (Southwood 1966) of herbivore communities among trap locations and gap ages.

\section{Results}

We collected a total of 18,583 herbivores representing 429 species, excluding adult Lepidoptera. Cicadellidae (Homoptera) was by far the most abundant family, with $>13,000$ specimens collected. More than 1,000 specimens were collected from each of the next two most abundant families: Chrysomelidae (Coleoptera) and Aphididae (Homoptera) (Table 1). In contrast, several families of Homoptera (Achilidae, Membracidae, Issidae), Hemiptera (Pentatomidae), and Orthoptera (Tettigoniidae) were infrequently collected and were represented by $<50$ specimens each (Table 1). Cicadellidae had the greatest species richness with 94 morphospecies followed by Chrysomelidae (71 species) and larval Lepidoptera (56 species), whereas Tettigoniidae, Achilidae, Psyllidae, Cercopidae, Issidae, and Flatidae had $<10$ morphospecies each (Table 1). Adult Lepidoptera were very well represented in the samples (Table 1) but 
Table 1. List, in decreasing abundance, of herbivorous insect groups collected in artificial canopy gaps in a South Carolina bottomland hardwood forest during 2001

\begin{tabular}{lrr}
\hline \hline \multicolumn{1}{c}{ Family (Order) } & $\begin{array}{c}\text { No. } \\
\text { species }\end{array}$ & $\begin{array}{c}\text { No. } \\
\text { individuals }\end{array}$ \\
\hline Cicadellidae (Homoptera) & 94 & 13,186 \\
Chrysomelidae (Coleoptera) & 71 & 1,481 \\
Aphididae (Homoptera) & 23 & 1,093 \\
Cixiidae (Homoptera) & 26 & 863 \\
Derbidae (Homoptera) & 15 & 404 \\
Flatidae (Homoptera) & 5 & 323 \\
Lygaeidae (Hemiptera) & 22 & 234 \\
Miridae (Hemiptera) & 32 & 222 \\
Immature Lepidoptera & 56 & 123 \\
Adult Lepidoptera & 303 & 15,292 \\
Delphacidae (Homoptera) & 13 & 118 \\
Thysanoptera ${ }^{a}$ & 1 & 102 \\
Cercopidae (Homoptera) & 6 & 85 \\
Acrididae (Orthoptera) & 12 & 85 \\
Psyllidae (Homoptera) & 6 & 77 \\
Pentatomidae (Hemiptera) & 16 & 45 \\
Achilidae (Homoptera) & 7 & 45 \\
Membracidae (Homoptera) & 10 & 39 \\
Issidae (Homoptera) & 6 & 38 \\
Tettigoniidae (Orthoptera) & 8 & 20 \\
Total herbivores ${ }^{b}$ & 429 & 18,583 \\
\hline
\end{tabular}

${ }^{a}$ The no. of species collected is not known because we only identified thrips to order.

${ }^{b}$ Totals do not include adult Lepidoptera.

were not included with herbivore totals because they are not active plant feeders. The forests surrounding young and old gaps had the most similar herbivorous insect assemblages, whereas those in the centers of young gaps and the forests surrounding them were the least similar (Table 2).

Overall abundance and species richness of herbivorous insects was greater at the center of young gaps than at other young or old gap locations (Fig. 1A and B). No differences in abundance or richness were observed among the three trapping locations for old gaps. Although insect richness and abundance was higher at the center of young gaps than at the center of old gaps, there were no such differences between gap ages for the edge or forest locations (Fig. 1A and B). Both herbivore richness and abundance increased with increasing gap size for the centers of young gaps, but these differences were not significant (Fig. 2A and $\mathrm{B})$. Herbivore richness was higher in young gaps than in old gaps regardless of gap size (Fig. 2A), and abundance was higher in the centers of the two smaller gap sizes but not in the 0.50-ha gaps (Fig. 2B).

Table 2. The percent similarity of herbivorous insects collected in young $(\approx 1 \mathrm{yr})$ or old $(\approx 7 \mathrm{yr})$ canopy gaps by location (center, edge, or $50 \mathrm{~m}$ into surrounding forest) in a South Carolina bottomland hardwood forest in $\mathbf{2 0 0 1}$

\begin{tabular}{lc}
\hline \multicolumn{1}{c}{ Comparison } & Similarity (\%) \\
\hline New forest versus old forest & 72.85 \\
New edge versus old edge & 63.60 \\
Old center versus old forest & 63.25 \\
New center versus old center & 48.91 \\
New center versus new forest & 47.25 \\
\hline
\end{tabular}

Most herbivore families or orders (Table 3) followed the overall trend (Fig. 1) for all herbivores combined, i.e., greater abundance and richness in young gap centers than at the edges or in the forest interior. Likewise, the abundance and species richness of many groups were higher in young gap centers than old gap centers. Cixiidae and Derbidae were the only groups captured in higher numbers in the forests near old gaps than in the gap centers, whereas no group was captured in higher numbers in forests near young gaps than in the centers of young gaps.

\section{Discussion}

Relatively little research has dealt with group selection cutting and its effects on forest ecosystems, but several studies have found insect abundance to be greater in canopy gaps than in closed forest (Hill et al. 2001, Gorham et al. 2002, Koivula and Niemelae 2003). Some studies suggest otherwise (Shelly 1988), but others involving insect predators (bats, Menzel et al. 2002; treefrogs, Cromer et al. 2002, Horn et al. 2005; and birds, Kilgo et al. 1999) lend support to the conclusion that gaps generally do contain greater abundances of insects. In this and related papers (Ulyshen et al. 2004, 2005), we report increases in the abundance and species richness of insects in young gaps, but older gaps and the forests surrounding them contained comparable numbers of insects. Only four families of herbivores showed any differences in morphospecies richness or abundance among old gap locations. The abundance and species richness of Miridae and the abundance of Flatidae were higher at the centers of old gaps than at the edges or in the forests surrounding old gaps, whereas Cixiidae and Derbidae exhibited the opposite response. In contrast, the abundance and species richness of all herbivore groups were either greater in young gaps compared with the surrounding forest or were approximately equal. In no case did we catch more in the forest.

Because they differed so greatly in the structure and composition of their respective plant communities, it is not surprising that young and old gaps contained quite different insect communities (48.91\%). Community similarity between old gaps and the forest surrounding old gaps was considerably greater $(63.25 \%)$ than the similarity between young gaps and the forest surrounding them $(47.25 \%)$, but both old and young gaps were considerably less similar to their respective forest locations than the two forest locations were to one other $(72.85 \%)$. These data suggest that $7 \mathrm{yr}$ is insufficient time for herbivorous insect communities to reach predisturbance conditions after canopy gap creation but that they are gradually becoming more like the surrounding forest herbivore community.

While the effects of gap age on insect communities were considerable, gap size had surprisingly little effect on their abundance or species richness. The percent area covered by vegetation in young gaps was about the same regardless of gap size ( $\mathrm{T}$. Champlin, personal communication), so the amount of vegetation, at least in young gaps, increased with increasing 


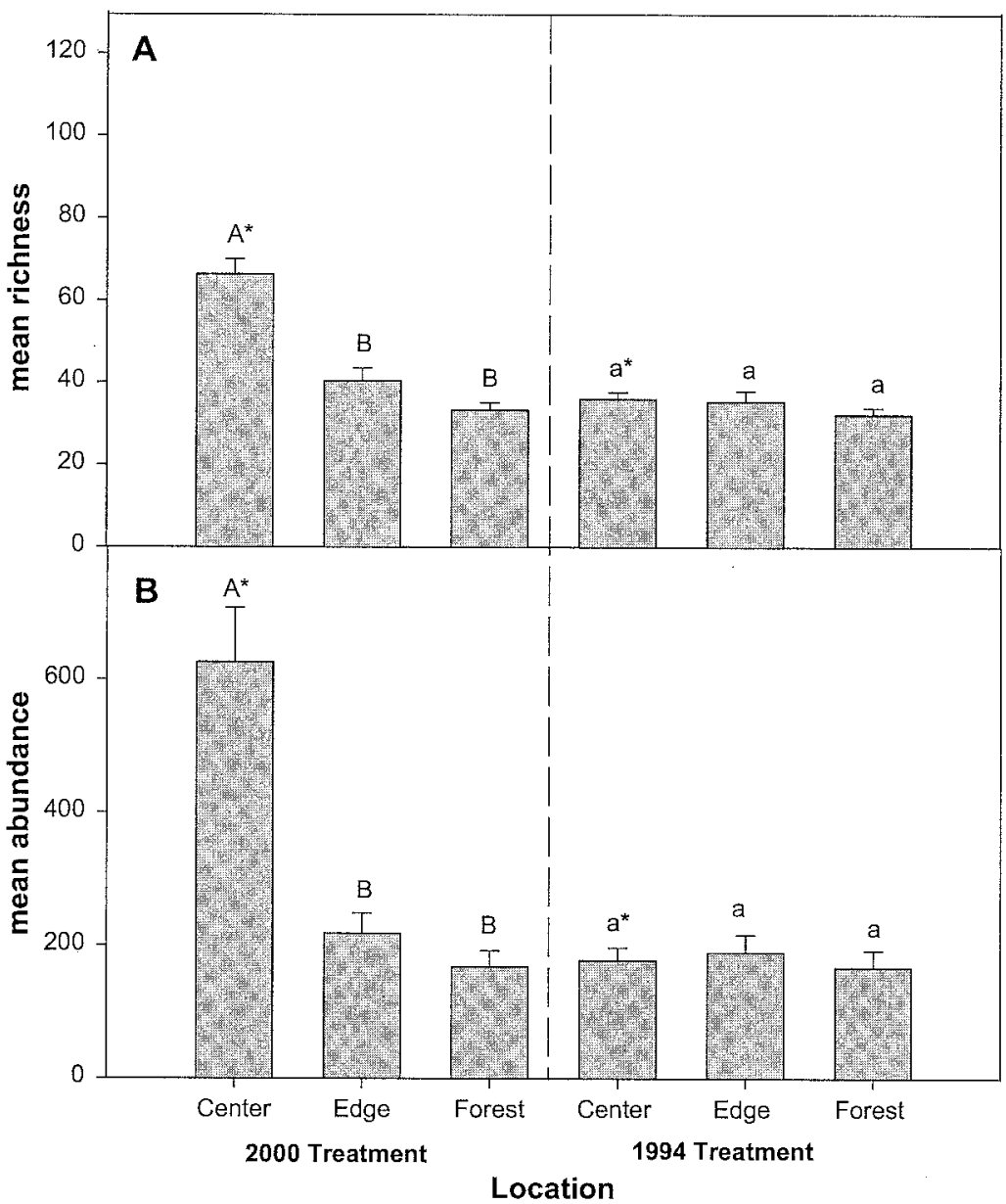

Fig. 1. Means \pm SE $(n=12)$ richness $(A)$ and abundance (B) of herbivorous insects collected in malaise and pitfall traps in 2001 at different locations in a bottomland hardwood forest in 1994 or 2000. Traps were placed at the center, edge, and in the nearby forest of each gap. Within graphs (for each treatment), bars with the same letter are not significantly different (Ryan-Einot-Gabriel-Welsch multiple range test, $P<0.05)$. Asterisks denote significant differences $(P<0.05)$ between the same trap locations (e.g., center versus center) in old (1994) and young (2000) gaps.

gap size. From this, we would have expected a similar increase in the abundance and possibly species richness of herbivorous insects. Although the trend was there, no significant difference in herbivore species richness or abundance among the gap sizes were detected. Because all traps have a limited sampling radius, malaise and pitfall traps may have somewhat hindered our ability to detect differences in insect abundance among different-sized gaps. Also malaise and pitfall traps are somewhat biased toward the most active species and generally overlook many species that are confined to their host plant. Systematically collecting insects throughout the gaps with vacuums or nets may have eliminated some limitations of passive trapping, but this may or may not have affected our results. Shure and Phillips (1991) used vacuum sampling to effectively measure differences in insect abundance between gaps of different size (0.016-10 ha), but they also found relatively little difference in herbivore (Homoptera and Hemiptera) abundance within the range of gap sizes considered in this study.

Our trapping procedure may also explain the difference between adult and larval Lepidoptera response to gap creation. The abundance and richness of caterpillars between old and young gaps was similar, whereas adults occurred in higher numbers in both old and young gap centers compared with the surrounding forest. Caterpillars were only collected in pitfall traps, so only larvae crawling across the ground were sampled. Because they are generally confined to their food plants and spend little time on the ground, caterpillars were probably underrepresented in our samples. In contrast, our malaise traps were well suited to sample adult Lepidoptera because they move readily in search of nectar, mates, and oviposition sites, and the trend for these (Table 3) more closely matched that for herbivores in general (Fig. 1). 


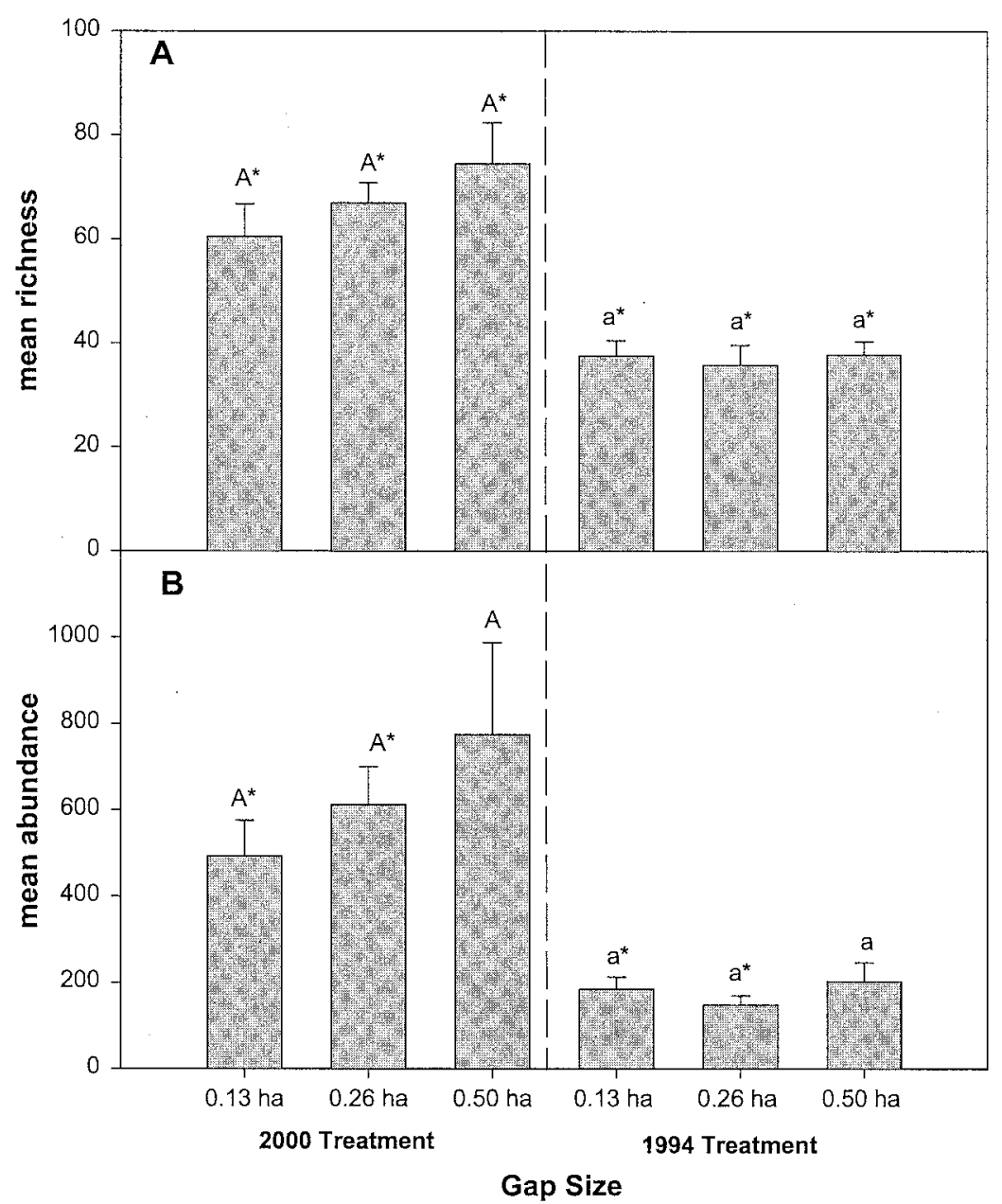

Fig. 2. Means \pm SE $(n=4)$ richness (A) and abundance $(B)$ of herbivorous insects collected in malaise and pitfall traps in 2001 at the centers of different-sized canopy gaps $(0.13,0.26$, and 0.50 ha) created in a bottomland hardwood forest in 1994 or 2000. Within graphs (for each treatment), bars with the same letter are not significantly different (Ryan-Einot-GabrielWelsch multiple range test, $P<0.05)$. Asterisks denote significant differences $(P<0.05)$ between the same trap locations (e.g., center versus center) in old (1994) and young (2000) gaps.

The comparatively high abundance and richness of herbivores observed in young gaps may be attributed in part to the abundance and palatability of the young plants growing there. Lawton and McNeill (1979) predicted that young foliage would support a higher abundance of herbivores than older foliage of the same species and that higher abundances would also be supported at earlier rather than later stages of succession. These predictions were supported in a study by Godfray (1985), in which the abundances of leaf miners were compared among different stages of succession. The apparent preference for plants in early rather than later stages of succession may be explained by increases in plant defenses with time (Lawton and McNeill 1979), softer leaves (Shure and Wilson 1993), fewer secondary plant compounds in the faster-growing pioneer species (Coley 1983, Denslow et al. 1990), and a greater availability of water
(Scriber and Slansky 1981) and nutrients (McNeill and Southwood 1978, Mattson 1980) in young tissues.

Although disparities in resource availability are likely to have affected herbivore numbers, other factors may have been important as well. For instance, some insects may have been drawn to gaps because of the relatively high light levels and temperatures there compared with the forest understory. Many may use the increased temperatures in gaps and other open areas to warm up on cold days. A number of herbivores were surely in the gaps for reasons other than herbivory, but their contribution to our results cannot be determined.

Despite these complications, the conditions in young gaps seem to encourage the colonization of a more abundant and species rich assemblage of insect herbivores. Of the 19 herbivorous insect groups considered in this study, 6 had significantly greater mor- 
Table 3. The mean $(n=12)$ abundance (top number) and richness (bottom number) of herbivorous insects collected at the center, edge, and in the surrounding forest of artificial canopy gaps in a bottomland hardwood forest, South Carolina, 2001

\begin{tabular}{|c|c|c|c|c|c|c|}
\hline & \multicolumn{3}{|c|}{ Young gaps } & \multicolumn{3}{|c|}{ Old gaps } \\
\hline & Gap & Edge & Forest & Gap & Edge & Forest \\
\hline \multicolumn{7}{|l|}{ Coleoptera } \\
\hline \multirow[t]{2}{*}{ Chrysomelidae } & $30.25 \pm 6.14 \mathrm{~A}$ & $23.33 \pm 6.95 \mathrm{~A}$ & $14.33 \pm 2.54 \mathrm{~A}$ & $18.58 \pm 2.69 \mathrm{a}$ & $19.33 \pm 4.54 \mathrm{a}$ & $17.58 \pm 2.67 \mathrm{a}$ \\
\hline & $9.92 \pm 0.65 \mathrm{~A}^{*}$ & $6.50 \pm 0.72 \mathrm{~B}$ & $5.67 \pm 0.50 \mathrm{~B}$ & $5.92 \pm 0.51 \mathrm{a}^{*}$ & $5.42 \pm 0.47 \mathrm{a}$ & $5.92 \pm 0.50 \mathrm{a}$ \\
\hline \multicolumn{7}{|l|}{ Hemiptera } \\
\hline \multirow[t]{2}{*}{ Lygaeidae } & $10.75 \pm 1.92 \mathrm{~A}$ & $2.17 \pm 0.58 \mathrm{~B}$ & $0.50 \pm 0.19 \mathrm{~B}$ & $2.92 \pm 0.99 \mathrm{a}$ & $1.42 \pm 0.31 \mathrm{a}$ & $1.75 \pm 0.81 \mathrm{a}$ \\
\hline & $4.08 \pm 0.51 \mathrm{~A}$ & $1.75 \pm 0.28 \mathrm{~B}$ & $1.08 \pm 0.08 \mathrm{~B}$ & $1.83 \pm 0.21 \mathrm{a}$ & $1.42 \pm 0.19 \mathrm{a}$ & $1.58 \pm 0.26 \mathrm{a}$ \\
\hline \multirow{2}{*}{ Miridae } & $8.33 \pm 1.56 \mathrm{~A}$ & $3.00 \pm 1.58 \mathrm{~B}$ & $0.75 \pm 0.35 \mathrm{~B}$ & $4.25 \pm 1.11 \mathrm{a}$ & $0.92 \pm 0.31 b$ & $1.25 \pm 0.37 \mathrm{~b}$ \\
\hline & $4.50 \pm 0.60 \mathrm{~A}^{*}$ & $1.50 \pm 0.19 \mathrm{~B}$ & $1.25 \pm 0.18 \mathrm{~B}$ & $2.75 \pm 0.41 a^{*}$ & $1.25 \pm 0.25 b$ & $1.50 \pm 0.29 b$ \\
\hline \multirow[t]{2}{*}{ Pentatomidae $^{a}$} & $1.25 \pm 0.22$ & $0.58 \pm 0.19$ & $0.42 \pm 0.29$ & $0.67 \pm 0.33$ & $0.42 \pm 0.26$ & $0.42 \pm 0.26$ \\
\hline & $1.25 \pm 0.13 \mathrm{~A}$ & $1.08 \pm 0.08 \mathrm{~A}$ & $1.00 \pm 0.00 \mathrm{~A}$ & $1.17 \pm 0.17 \mathrm{a}$ & $1.08 \pm 0.08 \mathrm{a}$ & $1.08 \pm 0.08 \mathrm{a}$ \\
\hline \multicolumn{7}{|l|}{ Homoptera } \\
\hline \multirow[t]{2}{*}{ Achilidae $^{c}$} & $2.33 \pm 1.24$ & $0.67 \pm 0.28$ & $0 \pm 0$ & $0.25 \pm 0.25$ & $0.33 \pm 0.19$ & $0.17 \pm 0.11$ \\
\hline & $1.33 \pm 0.19$ & $1.00 \pm 0$ & $1.00 \pm 0$ & $1.00 \pm 0$ & $1.00 \pm 0$ & $1.00 \pm 0$ \\
\hline \multirow{2}{*}{ Aphididae } & $37.00 \pm 11.24 \mathrm{~A}^{*}$ & $19.00 \pm 5.42 \mathrm{AB}$ & $6.25 \pm 1.01 \mathrm{~B}^{*}$ & $6.75 \pm 1.21 \mathrm{a}^{*}$ & $9.75 \pm 2.65 \mathrm{a}$ & $12.33 \pm 2.19 \mathrm{a}^{*}$ \\
\hline & $4.17 \pm 0.70 \mathrm{~A}$ & $4.25 \pm 0.64 \mathrm{~A}$ & $2.67 \pm 0.22 \mathrm{~A}$ & $2.83 \pm 0.41 \mathrm{a}$ & $3.75 \pm 0.79 a$ & $2.75 \pm 0.43 a$ \\
\hline \multirow{2}{*}{ Cercopidae $^{b}$} & $3.17 \pm 1.29 \mathrm{~A}$ & $0.83 \pm 0.24 \mathrm{~B}$ & $0.50 \pm 0.19 \mathrm{~B}$ & $1.42 \pm 0.50 \mathrm{a}$ & $0.58 \pm 0.29 \mathrm{a}$ & $0.58 \pm 0.15 \mathrm{a}$ \\
\hline & $1.33 \pm 0.14$ & $1.17 \pm 0.17$ & $1.08 \pm 0.08$ & $1.17 \pm 0.11$ & $1.00 \pm 0$ & $1.00 \pm 0$ \\
\hline \multirow[t]{2}{*}{ Cicadellidae } & $468.00 \pm 70.41 \mathrm{~A}^{*}$ & $143.67 \pm 26.45 \mathrm{~B}$ & $120.50 \pm 20.03 \mathrm{~B}$ & $124.33 \pm 17.58 a^{*}$ & $133.50 \pm 20.14 \mathrm{a}$ & $108.83 \pm 21.25 \mathrm{a}$ \\
\hline & $23.83 \pm 1.77 \mathrm{~A}^{*}$ & $13.42 \pm 1.42 \mathrm{~B}$ & $12.33 \pm 1.10 \mathrm{~B}$ & $13.25 \pm 0.98 \mathrm{a}^{*}$ & $12.08 \pm 0.80 \mathrm{a}$ & $11.42 \pm 0.76 \mathrm{a}$ \\
\hline \multirow{2}{*}{ Cixiidae } & $25.67 \pm 3.79 \mathrm{~A}^{*}$ & $11.25 \pm 3.25 \mathrm{~B}$ & $12.83 \pm 2.05 \mathrm{~B}$ & $2.00 \pm 0.44 \mathrm{a}^{*}$ & $9.17 \pm 2.07 \mathrm{~b}$ & $11.00 \pm 1.48 \mathrm{~b}$ \\
\hline & $4.92 \pm 0.58 \mathrm{~A}^{*}$ & $3.58 \pm 0.45 \mathrm{~A}$ & $3.92 \pm 0.51 \mathrm{~A}$ & $1.50 \pm 0.19 \mathrm{a}^{*}$ & $3.58 \pm 0.45 \mathrm{~b}$ & $3.42 \pm 0.47 \mathrm{~b}$ \\
\hline \multirow[t]{2}{*}{ Delphacidae } & $4.50 \pm 1.51 \mathrm{~A}$ & $1.33 \pm 0.38 \mathrm{~B}^{*}$ & $0.33 \pm 0.19 \mathrm{~B}$ & $0.75 \pm 0.41 \mathrm{a}$ & $0.25 \pm 0.13 \mathrm{a}^{*}$ & $2.67 \pm 2.11 \mathrm{a}$ \\
\hline & $2.42 \pm 0.40 \mathrm{~A}^{*}$ & $1.08 \pm 0.08 \mathrm{~B}$ & $1.08 \pm 0.08 \mathrm{~B}$ & $1.00 \pm 0 \mathrm{a}^{*}$ & $1.00 \pm 0 \mathrm{a}$ & $1.00 \pm 0 \mathrm{a}$ \\
\hline \multirow[t]{2}{*}{ Derbidae } & $11.42 \pm 2.13 \mathrm{~A}^{*}$ & $2.92 \pm 0.60 \mathrm{~B}$ & $5.33 \pm 1.52 \mathrm{~B}$ & $2.17 \pm 0.67 \mathrm{a}^{*}$ & $5.33 \pm 1.55 \mathrm{ab}$ & $6.50 \pm 1.33 \mathrm{~b}$ \\
\hline & $2.25 \pm 0.30 \mathrm{~A}$ & $1.83 \pm 0.30 \mathrm{~A}$ & $1.92 \pm 0.19 \mathrm{~A}$ & $1.67 \pm 0.28 \mathrm{a}$ & $2.42 \pm 0.43 \mathrm{a}$ & $1.83 \pm 0.24 a$ \\
\hline \multirow[t]{2}{*}{ Flatidae $^{b}$} & $11.08 \pm 1.62 \mathrm{~A}$ & $2.08 \pm 0.83 \mathrm{~B}$ & $0.75 \pm 0.28 \mathrm{~B}$ & $10.00 \pm 2.25 \mathrm{a}$ & $2.00 \pm 0.41 b$ & $1.00 \pm 0.39 b$ \\
\hline & $1.83 \pm 0.11$ & $1.33 \pm 0.19$ & $1.08 \pm 0.08$ & $1.75 \pm 0.18$ & $1.25 \pm 0.18$ & $1.08 \pm 0.08$ \\
\hline \multirow[t]{2}{*}{ Issidae $^{c}$} & $0.83 \pm 0.24$ & $0.58 \pm 0.26$ & $0.50 \pm 0.29$ & $0.58 \pm 0.34$ & $0.33 \pm 0.14$ & $0.33 \pm 0.14$ \\
\hline & $1.00 \pm 0$ & $1.00 \pm 0$ & $1.00 \pm 0$ & $1.25 \pm 0.18$ & $1.00 \pm 0$ & $1.00 \pm 0$ \\
\hline \multirow[t]{2}{*}{ Membracidae $^{a}$} & $0.25 \pm 0.13$ & $0.42 \pm 0.19$ & $0.75 \pm 0.30$ & $0.08 \pm 0.08$ & $1.33 \pm 1.07$ & $0.42 \pm 0.29$ \\
\hline & $1.00 \pm 0.00 \mathrm{~A}$ & $1.00 \pm 0.00 \mathrm{~A}$ & $1.17 \pm 0.11 \mathrm{~A}$ & $1.00 \pm 0.00 \mathrm{a}$ & $1.00 \pm 0.00 \mathrm{a}$ & $1.25 \pm 0.18 \mathrm{a}$ \\
\hline \multirow{2}{*}{ Psyllidae ${ }^{b}$} & $1.58 \pm 1.07 \mathrm{~A}$ & $2.00 \pm 0.90 \mathrm{~A}$ & $0.67 \pm 0.33 \mathrm{~A}$ & $0.42 \pm 0.23 a$ & $1.67 \pm 0.96 \mathrm{a}$ & $0.08 \pm 0.08 \mathrm{a}$ \\
\hline & $1.08 \pm 0.08$ & $1.08 \pm 0.08$ & $1.08 \pm 0.08$ & $1.00 \pm 0$ & $1.08 \pm 0.08$ & $1.00 \pm 0$ \\
\hline \multicolumn{7}{|l|}{ Lepidoptera } \\
\hline \multirow[t]{2}{*}{ Caterpillars } & $1.33 \pm 0.50 \mathrm{~A}$ & $2.67 \pm 0.31 \mathrm{~A}$ & $1.83 \pm 0.61 \mathrm{~A}$ & $1.83 \pm 0.34 \mathrm{a}$ & $1.67 \pm 0.53 \mathrm{a}$ & $0.92 \pm 0.19 \mathrm{a}$ \\
\hline & $1.42 \pm 0.23 \mathrm{~A}$ & $2.33 \pm 0.26 \mathrm{~A}$ & $2.08 \pm 0.53 \mathrm{~A}$ & $1.92 \pm 0.26 \mathrm{a}$ & $1.75 \pm 0.30 \mathrm{a}$ & $1.17 \pm 0.11 \mathrm{a}$ \\
\hline \multirow[t]{2}{*}{ Adults } & $350.33 \pm 31.11 \mathrm{~A}$ & $173.67 \pm 15.19 \mathrm{~B}$ & $130.17 \pm 12.06 \mathrm{~B}$ & $223.17 \pm 34.40 \mathrm{a}$ & $207.17 \pm 25.21 \mathrm{a}$ & $189.83 \pm 17.76 \mathrm{a}$ \\
\hline & $61.08 \pm 2.44 \mathrm{~A}^{*}$ & $41.83 \pm 2.13 \mathrm{~B}$ & $28.83 \pm 1.53 \mathrm{C}$ & $43.58 \pm 3.80 \mathrm{a}^{*}$ & $39.58 \pm 3.86 \mathrm{a}$ & $28.50 \pm 1.16 \mathrm{~b}$ \\
\hline Orthoptera & & & & & & \\
\hline Acrididae & $3.25 \pm 0.62 \mathrm{~A} *$ & $1.25 \pm 0.52 \mathrm{~B}$ & $0.58 \pm 0.29 \mathrm{~B}$ & $0.25 \pm 0.13 \mathrm{a}^{*}$ & $1.42 \pm 0.63 \mathrm{a}$ & $0.33 \pm 0.19 \mathrm{a}$ \\
\hline & $2.17 \pm 0.30 \mathrm{~A}^{*}$ & $1.42 \pm 0.19 \mathrm{~B}$ & $1.00 \pm 0.00 \mathrm{~B}$ & $1.00 \pm 0.00 \mathrm{a}^{*}$ & $1.25 \pm 0.18 \mathrm{a}$ & $1.00 \pm 0.00 \mathrm{a}$ \\
\hline Tettigoniidae $^{c}$ & $0.42 \pm 0.15$ & $0.25 \pm 0.18$ & $0.08 \pm 0.08$ & $0.33 \pm 0.14$ & $0.42 \pm 0.15$ & $0.17 \pm 0.17$ \\
\hline & $1.00 \pm 0.00$ & $1.00 \pm 0.00$ & $1.00 \pm 0.00$ & $1.00 \pm 0.00$ & $1.00 \pm 0.00$ & $1.08 \pm 0.08$ \\
\hline Thysanoptera $^{d}$ & $5.00 \pm 1.89 \mathrm{~A} *$ & $0.42 \pm 0.26 \mathrm{~B}$ & $1.33 \pm 0.43 \mathrm{AB}$ & $0.50 \pm 0.19 a^{*}$ & $0.25 \pm 0.18 \mathrm{a}$ & $1.00 \pm 0.33 \mathrm{a}$ \\
\hline
\end{tabular}

The young and old gaps were created in 2000 and 1994, respectively. For each gap age, values with the same letter are not significantly different (Ryan-Einot-Gabriel-Welsch multiple range test, $P<0.05)$. Asterisks denote significant differences $(P<0.05)$ between the same trap locations (e.g. center versus center) in young and old gaps.

${ }^{a}$ The abundance among locations is not compared statistically because of insufficient numbers $(<50$ specimens $)$.

${ }^{b}$ The species richness among locations is not compared statistically because of insufficient numbers ( $<10$ species).

${ }^{c}$ Both abundance and species richness are excluded from analysis because of insufficient numbers.

${ }^{d}$ Thrips were only identified to order so we have no measure of richness.

phospecies richness in young gaps compared with the forest and 11 were captured in higher numbers in young gaps. Six taxonomic groups had greater species richness in young gaps compared with old gaps, and five were captured in higher numbers in young gaps. In most cases, the other groups exhibited similar trends. After $7 \mathrm{yr}$ of succession, the abundance and species richness of insect herbivores were comparable with that of the surrounding forest, but the communities still differed considerably. These results indicate a substantial change in insect communities with time after gap creation. The relationships between insect and plant communities at other stages of succession and the time required for the herbivore community to return to preharvest levels remain largely unknown and warrant further study.

\section{Acknowledgments}

We thank S. Cahill, R. Malloy, W. Sikora, and L. Reynolds for sorting insects, D. Dyer and J. Campbell for helping with field work, and T. Champlin and L. Bowen for sharing vegetation data. Support was provided by the Department of Energy-Savannah River Operations Office through the U.S. Forest Service Savannah River under Interagency Agreement DE-AI09-00SR22188. Funding was provided by the 
National Research Initiative Competitive Grants Program of the USDA Cooperative State Research Education and Extension Service (Grant 00-35101-9307).

\section{References Cited}

Bach, C. E. 1990. Plant successional stage and insect herbivory: flea beetles on sand-dune willow. Ecology. 71: $598-609$

Boardman, N. K. 1977. Comparative photosynthesis of sun and shade plants. Annu. Rev. Plant Physiol. 28: 355-377.

Boring, L. R., C. D. Monk, and W. T. Swank. 1981. Early regeneration of a clear-cut southern Appalachian forest Ecology. 62: 1244-1253.

Bormann, F. H., and G. E. Likens. 1979. Pattern and process in a forested ecosystem. Springer, New York.

Breedlove, D. E., and P. R. Ehrlich. 1968. Plant-herbivore evolution: lupines and lycaenids. Science. 162: 671-672.

Brokaw, N.V.L. 1982. Treefalls: frequency, timing and consequences. In E. G. Leigh, A. S. Rand, and D. M. Windsor (eds.), The ecology of a tropical forest. Seasonal rhythms and long-term changes. Smithsonian Institute, Washington, DC. Pages 101-108.

Brown, V. K. 1984. Secondary succession: insect-plant relationships. Bioscience. 34: 710-716.

Brown, V. K. 1985. Insect herbivores and plant succession. Oikos. 44: 17-22.

Brown, V. K., and A. C. Gange. 1992. Secondary plant succession: how is it modified by insect herbivory? Vegetatio. 101: 3-13.

Clinton, B. D., L. R. Boring, and W. T. Swank. 1993. Canopy gap characteristics and drought influences in oak forests of the Coweeta Basin. Ecology. 74: 1551-1558.

Coley, P. D. 1983. Herbivory and defensive characteristics of tree species in a lowland tropical forest. Ecol. Monogr. 53: 209-233.

Cromer, R. B., J. D. Lanham, and H. H. Halin. 2002. Herpetofaunal response to gap and skidder-rut wetland creation in a southern bottomland hardwood forest. For. Sci. 48: 407-413.

Denslow, J. S., J. C. Schultz, P. M. Vitousek, and B. R. Strain. 1990. Growth responses of tropical shrubs to treefall gap environments. Ecology. 71: 165-179.

Godfray, H.C.J. 1985. The absolute abundance of leaf miners on plants of different successional stages. Oikos. 45: $17-25$.

Gorham, L. E., S. L. King, B. D. Keeland, and S. Mopper. 2002. Effects of canopy gaps and flooding on Homopterans in a bottomland hardwood forest. Wetlands. 22: 541549 .

Guldin, J. M. 1996. The role of uneven-aged silviculture in the context of ecosystem management. Western J. Appl. Forestry. 11: 4-13.

Hendrix, S. D., V. K. Brown, and A. C. Gange. 1988. Effects of insect herbivory on early plant succession: comparison of an English site and an American site. Biol. J. Linnean Soc. 35: 205-216.

Hill, J., K. Hamer, J. Tangah, and M. Dawood. 2001. Ecology of tropical butterflies in rainforest gaps. Oecologia (Berl.). 128: 294-302.

Horn, S., J. L. Hanula, M. D. Ulyshen, and J. C. Kilgo. 2005. Abundance of green tree frogs and insects in artificial canopy gaps in a bottomland hardwood forest. Am. Midland Naturalist. (in press).

Hunter, M. L. 1990. Wildlife, forests, and forestry. PrenticeHall, Englewood Cliffs, NJ.
Kilgo, J. C., K. V. Miller, and W. P. Smith. 1999. Effects of group-selection timber harvest in bottomland hardwoods on fall migrant birds. J. Field Ornithol. 70: 404-413.

Koivula, M., and J. Niemelae. 2003. Gap felling as a forest harvesting method in boreal forests: responses of carabid beetles (Coleoptera, Carabidae). Ecography. 26: 179187.

Lawton, J. H. 1978. Host-plant influences on insect diversity: the effects of time and space, pp. 105-125. In L. A Mound and N. Waloff (eds.), Diversity of insect faunas. Symposium of the Royal Entomological Society of London. Blackwell Scientific Publications, London, UK.

Lawton, J. H., and S. McNeill. 1979. Between the devil and the deep blue sea: on the problems of being a herbivore, pp. 223-244. In R. M. Anderson, B. D. Turner, and L. R Taylor (eds.), Population dynamics. Blackwell, Oxford.

Mattson, W. J. 1980. Herbivory in relation to plant nitrogen content. Ann. Entomol. Soc. Am. 11: 119-162.

Meadows, J. S., and J. A. Stanturf. 1997. Silvicultural systems for southern bottomland hardwood forests. For. Ecol. Manag. 90: 127-140.

McBrien, H., R. Harmsen, and A. Crowder. 1983. A case of insect grazing affecting plant succession. Ecology. 64: 1035-1039.

McNeill, S., and T.R.E. Southwood. 1978. The role of nitrogen in the development of insect/plant relationships. In J. B. Harborn (ed.), Biochemical aspects of plant and animal coevolution. Academic, London. Pages 77-98.

Menzel, M. A., T. C. Carter, J. M. Menzel, M. F. Ford, and B. R. Chapman. 2002. Effects of group selection silviculture in bottomland hardwoods on the spatial activity pattern of bats. For. Ecol. Manag. 162: 209-218

Murdoch, W. W., F. C. Evans, and C. H. Peterson. 1972. Diversity and pattern in plants and insects. Ecology. 53: $819-829$.

New, K. C., and J. L. Hanula. 1998. Effect of time elapsed after prescribed burning in longleaf pine stands on potential prey of the Red-Cockaded Woodpecker. South. J. Appl. Forestry. 22: 175-183.

Phillips, D. L., and D. J. Shure. 1990. Patch-size effects on early succession in southern Appalachian forests. Ecology. 71: 204-212.

Runkle, J. R. 1981. Gap regeneration in some old-growth forests of the eastern United States. Ecology. 62: 10411051.

Runkle, J. R. 1982. Patterns of disturbance in some oldgrowth mesic forests of eastern North America. Ecology. 63: 1533-1546.

SAS Institute. 1985. SAS guide for personal computers. Version 6. SAS Institute, Cary, NC.

Scriber, J. M., and F. Slansky, Jr. 1981. The nutritional ecology of immature insects. Annu. Rev. Entomol. 26: 183211.

Shelly, T. E. 1988. Relative abundance of day-flying insects in treefall gaps vs. shaded understory in a neotropical forest. Biotropica. 20: 114-119.

Shure, D. J., and D. L. Phillips. 1991. Patch size of forest openings and arthropod populations. Oecologia (Berl.) 86: 325-334.

Shure, D. J., and L. A. Wilson. 1993. Patch-size effects on plant phenolics in successional openings of the southern Appalachians. Ecology. 74: 55-67.

Southwood, T.R.E. 1966. Ecological methods with particular reference to the study of insect populations. Butler and Tanner, London.

Southwood, T.R.E., V. K. Brown, and P. M. Reader. 1979. The relationships of plant and insect diversities in succession. Biol. J. Linnean Soc. 12: 327-348. 
Ulyshen, M. D., J. L. Hanula, S. Horn, J. C. Kilgo, and C. E. Moorman. 2004. Spatial and temporal patterns of beetles associated with coarse woody debris in managed bottomland hardwood forests. For. Ecol. Manag. 199: $259-272$.

Ulyshen, M. D., J. L. Hanula, S. Horn, J. C. Kilgo, and C. E. Moorman. 2006. The response of ground beetles (Coleoptera: Carabidae) to selection cutting in a South Carolina bottomland hardwood forest. Biodiversity Conserv. (in press).

White, P. S., M. D. MacKenzie, and R. T. Busing. 1985. Natural disturbance and gap phase dynamics in southern
Appalachian spruce-fir forests. Can. J. For. Res. 15: 233240.

White, T.C.R. 1978. The importance of a relative shortage of food in animal ecology. Oecologia (Berl.). 33: 71-86.

Wilder, C. M., F. W. Holtzclaw, Jr., and E.E.C. Clebsch. 1999. Succession, sapling density and growth in canopy gaps along a topographic gradient in second growth east Tennessee forest. Am. Midland Naturalist. 142: 201-212.

Received for publication 12 June 2004; accepted 20 January 2005 